\title{
Biologi Penghisap Buah Helopeltis sp. (Hemiptera: Miridae) pada Buah Kakao dan Mentimun
}

\author{
Biology of Mirid bug Helopeltis sp. (Hemiptera: Miridae) in Cocoa and Cucumber \\ Novri Nelly ${ }^{1)^{*}}$ Ujang Khairul| ${ }^{1)}$ dan Puput Januasari ${ }^{1)}$ \\ 1) Program Studi Proteksi tanaman Fakultas Pertanian Universitas Andalas Padang \\ 2) Program Studi Agroteknologi Fakultas Pertanian Universitas Andalas Padang \\ *E-mail: novrinelly@agr.unand.ac.id
}

\begin{abstract}
This research purposed to study biology of Helopeltis sp. on cocoa and cucumber fruits. Research was done in insect bioecology laboratory using direct observation with 10 replications for each fruit. Parameter observed were copulation (hours), preoviposition time (days), number of eggs, nymphals, and adult periods (days), Oviposition time (days), and post oviposition time (days). The data obtained were analyzed descriptively and compared with t-test. Result of this research showed that Helopeltis sp. could thrive in cacao and cucumber fruits. Adult of Helopeltis sp. longevity in cacao fruits was 16 days and in cucumber fruits was 13 days. The number of eggs product average 10-10.9 eggs/female.
\end{abstract}

Key words: biology, Helopeltis sp., cacao, mentimun

\section{PENDAHULUAN}

Hama penghisap buah Helopeltis sp. (Hemiptera: Miridae) merupakan hama utama dalam budidaya kakao. Ada beberapa spesies yang dilaporkan menyerang tanaman kakao, antara lain. $H$. bradyi (Melina et al. 2016), $H$. antonii, $H$. theivora, dan $H$. Claviver. Hama ini merupakan salah satu hama yang menjadi kendala dalam upaya peningkatan produksi kakao. Serangan berat dapat menyebabkan penurunan produksi hingga 50\% (Indriani, 2004).

Hama ini menyerang berbagai bagian tanaman seperti pucuk dan buah. Apabila pucuk dan buah kakao terserang, maka produksi kakao akan mengalami penurunan yang sangat signifikan. Serangan pada buah muda sangat merugikan. Buah yang terserang menunjukkan bekas tusukan berupa bercak-bercak hitam pada permukaan buah. Pada serangan berat, seluruh permukaan buah dipenuhi oleh bekas tusukan berwarna hitam dan kering, kulitnya mengeras serta retak-retak. Serangan berat pada buah muda yang berukuran kurang dari $5 \mathrm{~cm}$ menyebabkan buah kering dan rontok (Soenaryo dan Situmorang, 1978).

Selain kakao, hama ini juga menyerang banyak tanaman lain, diantaranya teh, jambu biji, jambu mete, mangga, ubi jalar dan mentimun sebagai inang alternatif. Mentimun juga merupakan inang yang disukai oleh Helopeltis sp. Hama ini dapat hidup dan berkembangbiak dengan baik pada mentimun. Helopeltis sp. hidup dengan baik pada ketinggian 200-1.400 $\mathrm{m} / \mathrm{dpl}$. Keadaan cuaca dan persediaan makanan mempengaruhi kecepatan perkembangbiakan serangga Helopeltis sp. Hama ini menyukai lingkungan yang teduh dengan kelembaban sedang dan peka 
terhadap sinar matahari langsung, sehingga kondisi pertanaman yang rimbun dan kotor sangat disukai oleh hama ini (Atmadja, 2008).

Penelitian biologi hama diperlukan sebagai dasar pengendalian, memudahkan penentuan stadia yang rentan sehingga dapat mengurangi kerugian pada tanaman kakao. Hal ini juga diperlukan terutama untuk perbanyakan di laboratorium, yaitu sebagai serangga uji untuk menemukan teknik pengendalian hama ini ke depannya. Sampai saat ini, belum banyak informasi yang lengkap mengenai biologi Helopeltis sp. pada buah kakao dan buah mentimun. Telah dilakukan penelitian dengan tujuan untuk mempelajari biologi Helopeltis sp. pada buah kakao dan buah mentimun.

\section{METODOLOGI}

Penelitian dilakukan di Laboratorium Bioekologi Serangga Fakultas Pertanian, Universitas Andalas, Padang, pada bulan November 2014 sampai Januari 2015.

\section{Metode}

Pengamatan biologi Helopeltis sp dilakukan secara langsung di laboratorium pada mentimun dan kakao, masingmasing dilaksanakan dalam sepuluh kali ulangan.

\section{Penyediaan Helopeltis sp}

Helopeltis sp. yang digunakan dalam penelitian ini berasal dari pertanaman kakao di Kabupaten Padang Pariaman, Kecamatan Sungai Geringging. Nimfa Helopeltis sp. yang ditemukan diambil dengan mengguna-kan kuas kecil dan imago Helopeltis sp. diambil langsung menggunakan tangan, dimasukkan ke dalam kotak serangga (panjang $24 \mathrm{~cm}$, lebar $16 \mathrm{~cm}$ dan tinggi $9 \mathrm{~cm}$ ), kemudian dibawa dan dipelihara di laboratorium. Pisahkan Helopeltis sp. yang jantan dan betina ke dalam kurungan pemeliharaan (kotak plastik dengan lebar $10 \mathrm{~cm}$ dan tinggi $10 \mathrm{~cm}$ ) yang diatasnya ditutupi dengan kain kasa, kemudian di beri buah mentimun dan buah kakao sebagai pakan.

Satu pasang Helopeltis sp. (F1) yang baru terbentuk, dimasukkan ke dalam kurungan pemeliharaan (tinggi 10 $\mathrm{cm}$ dan lebar $10 \mathrm{~cm}$, diisi dengan pakan mentimun dan kakao yang sudah dibersihkan dan dikering anginkan. Bagian atas kurungan pemeliharaan ditutupi dengan kain kasa. Pakan diganti sekali dua hari, masing-masing diulang 10 kali ulangan. Selanjutnya dilakukan pengamatan terhadap biologi Helopeltis sp.

\section{Parameter pengamatan Waktu kopulasi (jam)}

Sepasang imago Helopeltis sp. dimasukkan ke dalam kurungan pemeliharaan, kemudian diamati dan dihitung berapa lama kopulasi berlangsung.

\section{Waktu pra oviposisi (hari)}

Waktu pra oviposisi dihitung dari pertama imago Helopeltis sp. terbentuk dan dimasukkan ke dalam kurungan pemeliharaan sampai meletakkan telur yang pertama kali.

\section{Jumlah telur (butir)}

Pengamatan terhadap jumlah telur dilakukan setiap hari terhitung mulai dari telur pertama sampai telur terakhir diletakkan oleh imago betina Helopeltis sp.

\section{Lama stadia telur (hari)}

Pengamatan untuk lama stadium telur terhitung mulai dari telur diletakkan sampai telur menetas menjadi nimfa. Pengamatan pada stadium telur dilakukan setiap hari.

\section{Lama stadia nimfa (hari)}

Pengamatan untuk lama stadia nimfa, dihitung dari pertama kali nimfa terbentuk, dan mengalami pergantian 
Nelly et al. Biologi Penghisap Buah Helopeltis sp.

kulit atau disebut juga dengan instar 1, 2, 3, 4, dan 5 sampai menjadi imago.

\section{Lama stadia imago (hari)}

Pengamatan untuk lama stadia imago, dihitung sejak terbentuknya imago jantan dan betina sampai imago jantan dan betina tersebut mati.

\section{Waktu oviposisi (hari)}

Waktu oviposisi dihitung mulai dari imago betina pertama kali meletakkan telur sampai telur terakhir diletakkan.

\section{Waktu pasca oviposisi (hari)}

Waktu pasca oviposisi dihitung mulai dari terakhir kali imago betina meletakkan telur sampai imago betina mati.

\section{Pola peneluran imago betina (butir)}

Pola peneluran imago betina Helopeltis sp. diamati dari jumlah telur yang diletakkan setiap hari sampai hari terakhir peneluran.

\section{Analisis data}

Data yang didapatkan dari masingmasing parameter pengamatan dilakukan analisis deskriptif dan dibandingkan dengan uji-t.

Tabel 1. Parameter kehidupan Helopeltis sp. pada buah mentimun dan buah kakao

\begin{tabular}{lrrrrrr}
\hline \multirow{2}{*}{ Parameter } & \multicolumn{3}{c}{ Mentimun } & \multicolumn{3}{c}{ Kakao } \\
\cline { 2 - 7 } & Min & Max & Rata-rata & Min & Max & Rata-rata \\
\hline Kopulasi (jam) & 1 & 3 & 2,0 & 1 & 3 & 1,9 \\
Waktu pra oviposisi (hari) & 3 & 4 & 3,6 & 3 & 5 & 4,2 \\
Jumlah telur (butir) & 7 & 11 & 10,0 & 8 & 12 & 10,6 \\
Lama stadia telur (hari) & 6 & 8 & 6,7 & 6 & 8 & 7,0 \\
Lama stadia nimfa (hari) & 11 & 13 & 12,0 & 11 & 13 & 12,0 \\
Lama stadia imago (hari) & 9 & 13 & 10,8 & 12 & 16 & 13,5 \\
Waktu oviposisi (hari) & 3 & 4 & 3,4 & 3 & 5 & 4,3 \\
Waktu pasca oviposisi(hari) & 3 & 6 & 4,1 & 4 & 7 & 5,2 \\
\hline
\end{tabular}

\section{Parameter kehidupan Helopeltis sp.}

Hasil pengamatan menunjukkan bahwa secara umum parameter kehidupan Helopeltis sp pada buah mentimun dan kakao cenderung sama, perbedaan yang menyolok terlihat pada lama stadia imago masing-masing terpaut 3 hari, baik minimum maupun maksimum. Parameter kehidupan Helopeltis sp. pada buah mentimun dan buah kakao dapat dilihat pada Tabel 1.

\section{Biologi Helopeltis sp}

Tidak ada perbedaan waktu kopulasi, jumlah telur, lama stadia telur, lama stadia nimfa nimfa Helopeltis sp. pada mentimun dan kakao. Sedangkan pada waktu pra oviposisi, lama stadia imago, waktu oviposisi dan waktu pasca oviposisi Helopeltis sp. terlihat perbedaan yang nyata. Waktu pra oviposisi, lama stadia imago, waktu oviposisi dan waktu pasca oviposisi Helopeltis sp pada mentimun lebih rendah daripada kakao. Selengkapnya dapat dilihat pada Tabel 2. 
Tabel 2. Parameter kehidupan Helopeltis sp pada buah mentimun dan buah kakao setelah dilakukan uji $\mathrm{t}$

\begin{tabular}{lcrc}
\hline \multirow{2}{*}{ Parameter } & \multicolumn{2}{c}{ Rata-rata } & \multirow{2}{*}{ Uji t } \\
\cline { 2 - 3 } Kopulasi (jam) & Mentimun & Kakao & \\
Waktu pra oviposisi (hari) & 3,0 & 1,9 & $0,66^{\text {tn }}$ \\
Jumlah telur (butir) & 10,0 & 4,2 & $2,32^{*}$ \\
Lama stadia telur ((hari) & 6,7 & 10,6 & $0,97^{\text {tn }}$ \\
Lama stadia nimfa (hari) & 12,0 & 7,0 & $0,82^{\text {tn }}$ \\
Lama stadia imago (hari) & 10,8 & 12,0 & $0,00^{\text {tn }}$ \\
Waktu oviposisi (hari) & 3,4 & 4,5 & $4,67^{*}$ \\
Waktu pasca oviposisi (hari) & 4,1 & 5,2 & $2,93^{*}$ \\
\hline Keteran & $2,43^{*}$ \\
\hline
\end{tabular}

Keterangan jika t hitung > dari t table 1,73 (one-tail) 2,10(two-tail) maka berbeda nyata pada uji-t dengan taraf nyata $5 \%{ }^{*}=$ berbeda nyata, ${ }^{\mathrm{tn}}=$ berbeda tidak nyata

\section{Perkembangan jumlah telur yang diletakkan}

Perkembangan jumlah telur yang diletakkan imago betina pada buah kakao dan mentimun dapat dilihat pada Gambar 1. Rata-rata jumlah telur yang diletakkan dari hari pertama sampai ketiga pada buah tersebut adalah sama (3 butir), namun pada hari keempat terjadi penurunan jumlah telur pada buah mentimun dan kakao ( 2 butir). Pada hari kelima jumlah telur yang diletakkan pada buah kakao menurun menjadi 1 butir, sedangkan pada buah mentimun tidak ada telur yang diletakkan.

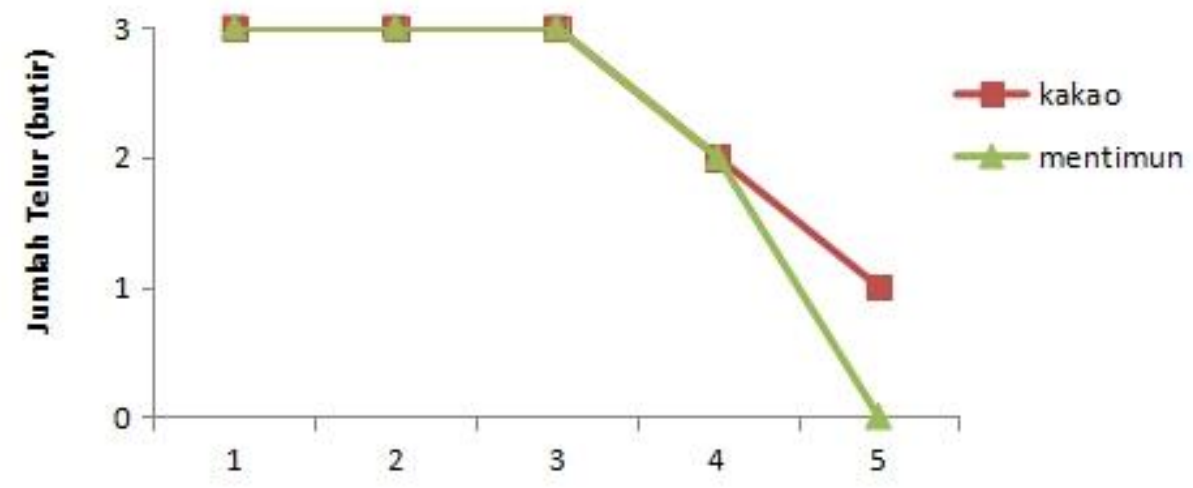

Hari Ke-

Gambar 1. Perkembangan jumlah telur yang diletakkan imago betina Helopeltis sp. pada buah mentimun dan kakao

\section{PEMBAHASAN}

Secara umum, setiap parameter kehidupan Helopeltis sp. pada buah mentimun dan buah kakao cenderung sama, kecuali pada lama stadia imago (Tabel 1). Hasil uji t menunjukkan bahwa waktu pra oviposisi, lama stadia imago, waktu oviposisi dan waktu pasca oviposisi Helopeltis sp pada mentimun lebih pen- dek daripada kakao, sementara parameter kehidupan lainnya tidak berbeda nyata (Tabel 2). Rata-rata jumlah telur yang diletakkan sama dan cenderung menurun. Jumlah telur pada hari pertama sampai ketiga pada buah tersebut adalah sama (3 butir), namun pada hari keempat terjadi penurunan jumlah telur pada buah mentimun dan kakao ( 2 butir). Pada hari 
kelima jumlah telur yang diletakkan pada buah kakao menurun menjadi 1 butir, sedangkan pada buah mentimun tidak ada telur yang diletakkan (Gambar 1).

Makhluk hidup memerlukan nutrisi untuk pertumbuhan dan perkembangannya. Mangoendihardjo et al., (1988) menyatakan bahwa nutrisi berhubungan dengan proses berbagai substansi yang didapat dari makanan utama menjadi bahan-bahan penyusun tubuh dan energi untuk melakukan segala aktivitas hidupnya. Kebutuhan nutrisi tergantung pada kemampuan sintetis dan sifat dasar genetik makhluk hidup, sehubungan dengan nutrisi tersebut, ada hubungan langsung dan esensial antara faktor lingkungan, pakan utama, dan proses vital suatu serangga.

Pakan merupakan salah satu faktor yang dapat mempengaruhi kehidupan serangga, sedangkan ma-kanan itu sendiri ditentukan oleh kualitas dan kuantitasnya. Makanan harus memenuhi persyaratan untuk pertumbuhan dan perkembangannya. Perbedaan kualitas dan kuantitas pakan dipengaruhi oleh perbedaan dalam komposisi karbohidrat, protein, lemak, dan air (Sunjaya, 1970). Ketidakseimbangan atau tidak tersedianya zat-zat tertentu didalam pakan dapat menghambat pertumbuhan serangga, sehingga menjadi tidak normal (Chapman, 1971).

Pada Tabel 1 dan Tabel 2 dapat dilihat bahwa jumlah telur yang diletakkan imago betina Helopeltis sp. pada buah mentimun adalah berkisar antara 7-11 butir, sedangkan pada buah kakao berkisar antara 8-12 butir dengan lama stadia telur pada masing-masing buah berkisar 6-8 hari. Hal ini sesuai dengan pernyataan Sudarmadji (1979) bahwa telur Helopeltis sp. mulai menetas menjadi nimfa pada waktu 6-8 hari. Stadia nimfa pada kedua pakan membutuhkan waktu 11-13 hari, ini sesuai dengan pernyataan (Atmadja, 2012) bahwa waktu yang diperlukan oleh Helopeltis sp. sejak menetas sampai menjadi dewasa berkisar 11-15 hari. Lama pergantian kulit pertama, kedua, ketiga, dan keempat adalah 2-3 hari, sedangkan lama instar kelima 3-4 hari. Hasil pengamatan waktu pasca oviposisi Helopeltis sp. pada buah kakao terjadi pada 4-7 hari. Hal ini tidak jauh berbeda dibandingkan dengan pasca oviposisi Helopeltis sp. pada buah mentimun yang terjadi pada 3-6 hari.

Pengamatan biologi Helopeltis sp. pada mentimun dan kakao ditemukan data yang hampir sama. Helopeltis sp. mengalami metamorfosis yang tidak sempurna (Paurometabola), yaitu terdiri dari telur, nimfa dan imago. Telur mulai diletakkan serangga betina pada hari ketiga sampai hari kelima saat serangga menjadi dewasa. Telur diletakkan secara berkelompok 2-4 butir dalam jaringan buah. Helopeltis sp. mampu bertelur dalam satu siklus hidup sebanyak 12 butir. Telur diletakkan pada jaringan buah yang lunak melalui ovipositor Helopeltis sp. $\mathrm{Hal}$ ini sesuai dengan pernyataan (Kilin dan Atmadja, 2000) telur diletakkan secara berkelompok, diletakkan pada jaringan tanaman yang lunak seperti bakal buah dan buah yang masih muda. Lama stadia imago pada buah mentimun berkisar dari 9-13 hari, sedangkan pada buah kakao 1216 hari. Hal ini sesuai dengan pernyataan (Atmadja, 2003) yang mengatakan bahwa lama hidup serangga ini berkisar 8-52 hari.

\section{KESIMPULAN}

Helopeltis sp dapat hidup dengan baik pada buah mentimun dan buah kakao. Waktu pra oviposisi, lama stadia imago, waktu oviposisi dan waktu pasca oviposisi Helopeltis sp pada mentimun lebih pendek daripada kakao, sementara parameter kehidupan lainnya tidak berbeda nyata. Jumlah telur yang diletakkan cenderung hampir sama dan cenderung menurun. Pada hari kelima, 
Nelly et al. Biologi Penghisap Buah Helopeltis sp.

tidak ada telur yang diletakkan pada buah mentimun.

\section{DAFTAR PUSTAKA}

Atmadja WR. 2003. Status Helopeltis antonii sebagai hama pada beberapa tanaman perkebunan dan pengendaliannya. Balai Penelitian Tanaman Rempah dan Obat. Bogor. Jurnal Litbang Pertanian 22 (2); 57-63.

Atmadja WR. 2008. Pengaruh minyak jahe merah dan selasih terhadap Helopeltis antonii Sign pada inang alternatif. Buletin 2 : 154-163.

Atmadja WR. 2012. Pengendalian Helopeltis sp. secara terpadu pada tanaman perkebunan. Unit Penerbitan dan Publikasi Balittro.

Chapman RF. 1971. The insect structure and function. The English University Press Ltd. London.

Indriani DP. 2004. Pengelolaan perkebunan kakao dalam mengatasi serangan Helopeltis antonii dan $H$. theivora menuju agroekosistem kakao berkelanjutan di Afdeling Rajamandala PTPN VIII. Jawa Barat. Kumpulan Abstrak Tesis-Disertasi. ITB Central Library. Bandung.

Kilin D dan Atmadja WR. 2000. Perbanyakan serangga Helopeltis antonii Signoret pada Buah Ketimun dan Pucuk Jambu Mete. Jurnal Penelitian Tanaman Industri $\mathrm{V}$.

Mangoendihardjo SF, Wagiman $X$ dan Irianti ATP. 1988. Uji pakan buatan untuk pemeliharaan Curinus coeruleus Mulsant. Prosiding Lokakarya Penelitian dan Penanggulangan Kutu Loncat Lamtoro. Universitas Gajah Mada dan Perhimpunan Entomologi Indonesia. Yogyakarta.

Melina S, Martono E dan Trisnoyo A. 2016. Confirmation that Helopeltis species attacking cacao in Yogyakarta is Helopeltis bradyi Waterhouse, not Helopeltis antonii Signoret (Heteroptera: Miridae). Jurnal Entomologi Indonesia 13 (1); 9-20.

Soenaryo dan Situmorang. 1978. Budidaya coklat dan pengelolaannya. Balai Penelitian Perkebunan Bogor.

Sudarmadji D. 1979. Pembiakan Helopeltis antonii di laboratorium. Kongres Biologi Nasional IV Bandung.10-12 juli 1979.

Sunjaya PI. 1970. Dasar-dasar ekologi serangga. Bagian Ilmu Hama Tanaman Pertanian IPB. Bogor. 